\title{
熊本大眼科における不同視弱視の治療成績
}

\author{
河上なつみ・帆足悠美子 ・ 高木満里子 \\ （熊本大学医学部附属病院眼科）
}

\section{Studies on Prognosis in Anisometropic Amblyopia}

\author{
Natumi KAWAKAMI, Yumiko HOASHI, Mariko TAKAKI
}

(Department of Ophthalmology, Kumamoto University Medical School)

\begin{abstract}
昭和 54 年から昭和 63 年の過去 10 年間に熊本大眼科外来を受診した 3 歳から 15 歳までの不同視弱視患者 86 症 例を, 最終視力が 0.8 以上と 0.8 未満, あるいは初診時視力が 0.3 以上と 0.3 未満に分類し, 初診時年齢, 弱視 眼屈折度, 不同視差, の各項目について, 視力との関係の有無を検討した.

その結果, (1)最終視力が0.8以上と0.8末満の群とでは, 0.8 未満の方が初診時視力の悪い症例の占める割合 が高かった. (2)初診時視力0.3以上と0.3未満の群では視力向上の程度に差は見られなかった。 (3)初診時年齢, 弱視眼屈折度, 不同視差と視力の間には関係が見られなかった. (4)不同視の程度は初診時視力が 0.3 以の 群の方が0.3未満に比べ軽かった。
\end{abstract}

The present study was undertaken to determine the relation between visual acuity of the patients with anisometropic amblyopia and the following factors:(1) age of initial examination, (2) follow-up period, (3) refraction of the amblyopic eye and (4) degree of anisometropia. We studied eighty six patients seen at the Kumamoto University Hospital from 1979 to 1988 . Their age on initial examination was ranged from 3 to 15 years.

Patients were devided into A-group, composed of patients with final vision of 0.8 or better and B-group, composed of patients with final vision of lower than 0.8. And according to the initial vision, all patients were also devided into C-group, composed of patients with initial vision of 0.3 or better and D-group, composed of patients with initial vision of lower than 0.3 .

When A-group was compared with B-group, initial vision was lower in B-group. Degree of anisometropia was lower in C-group than in D-group. However, there was no significant difference in the degree of visual improvement between C-group and D-group. No significant relation was found between visual acuity and age of initial examination, follow-up period, degree of anisometropia or refraction of the amblyopic eye.

\section{I . 緒言 \\ 不同視弱視は一般に治療によって視力が回復 しやすいとされているが1)，実際にはなかなか視}

力が向上しない例も経験する.今回私共は, 過 去10年間に熊本大眼科外来を受診した不同視弱 視患者について，視力低下の要因および視力向 上に関与する因子について検討を試みたのでこ

連絡先（テ860）熊本市本荘 $1-1-1$ 熊本大学医学部附属病院 眼科

河上なつみ

Tel. 096-344-2111 内 5734

key words: Anisometropic Amblyopia,

refraction,

degree of anisometropia. 
こに報告する．

\section{II. 対象および方法}

対象：昭和 54 年 1 月から昭和 63 年 12 月までの 10年間に熊本大眼科外来を受診した15歳までの 不同視弱視患者のうち, (1) 左右眼の屈折度数 の差が2.0D以上，または弱視眼の乱視度数が $1.5 \mathrm{D}$ 以上 $^{2,3)}(2)$ 斜視がない( 3 ) 中心固視 (4) 1 年以上経過観察が行えたもの, 以上 (1)〜 (4) の条件を満たす 86 症例とした。乱視を有してい る症例については，各眼とも最小錯乱円にてそ の眼の屈折度数とみなした。

対象の初診時年齢は 3 歳から14歳までで平均 7.1 歳, 経過観察期間は 1 年から最長 11 年 3 力月, 平均 3 年 6 力月であった.

方法：視力は初診時の他覚的屈折検査の值を もとにした矯正視力を初診時視力, 最終来院時 の矯正視力を最終視力とした。初診時視力は非 弱視眼 0.8 以上であり, 弱視眼は 0.03 から 0.7 ま でであった。まず，全症例のうち弱視眼の最終 視力が 0.8 以上に達したもの (42例)を A 群, 0.8未 満(44例)をB群とに分けた。またこれとは別に 教育上からみた弱視の分類から, 初診時の視力 が0.3以上 (35例) を C 群，0.3末満 (51例) を D群 とする 2 通りの方法で分類し初診時視力, 最終 視力, 初診時年齢, 弱視眼屈折度, 不同視差につ いて比較検討を行った.なお統計学的検定には カイ 2 乗検定を用いた.

\section{III. 結 果}

\section{1. 初診時視力と最終視力}

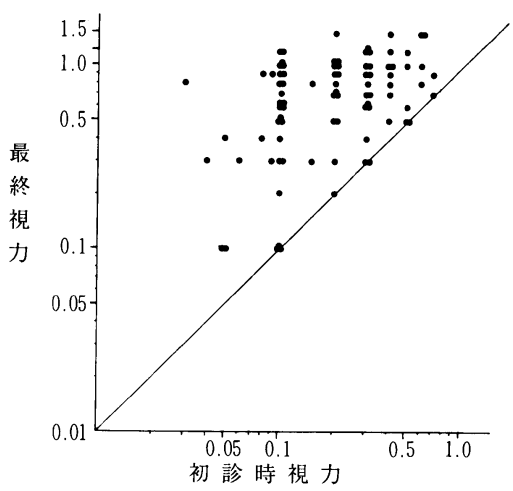

図 1. 全症例の初診時視力と最終視力
図 1 に86名の初診時視力と最終視力とを示し た. 治療後, 弱視眼の視力の改善が見られなか った症例は 9 例であった．弱視眼において最終 視力が 0.8 以上に達した $\mathrm{A}$ 群 42 例のうち，21例 $(50 \%)$ が初診時視力 0.3 以上を有し，また最終視 力が0.8に満たなかったB群においては, 初診時 視力が 0.3 以上のものは44例中14例 (32\%)であっ た(表 1 ).ここで視力向上の状態を見るために，

表 1

\begin{tabular}{|c|c|c|}
\hline & $\begin{array}{c}\text { 最終視力 } \\
0.8 \text { 末満 }\end{array}$ & $\begin{array}{c}\text { 最終視力 } \\
0.8 \text { 以上 }\end{array}$ \\
\hline $\begin{array}{c}\text { 初診時視力 } \\
0.3 \text { 未満 }\end{array}$ & 30 (人) & 21 (人) \\
\hline $\begin{array}{c}\text { 初診時視力 } \\
0.3 \text { 以上 }\end{array}$ & 14 (人) & 21 (人) \\
\hline
\end{tabular}

もう一つの分類方法である初診時視力の良かっ たC群と悪かったD群とについて，準標準視力 表にて何段階視力が向上したかを比較した。そ の結果, 初診時の視力より 4 段階以上の向上を 見たのはC群21例 (60\%), D群34例 (67\%)，ま た，5段階以上ではC群17例 (49\%)，D群29例 $(57 \%)$ であり，初診時視力の違いによって視力 向上の程度に大きな差は見られなかった。

\section{2. 視力と初診時年龄}

初診時年齢については，過去の報告と同様年 齢が高い傾向が見られ，最年少は 3 歳児で 1 名 のみである。6 歳で初診した例が最も多く，次 いで 7 歳となっており両者を合せると44例（51 \%) と全体の半数を占めていた (図 2 ). 受診の 動機も就学時あるいは学校健康診断での指摘が 大部分であった．最終視力と初診時年齢につい ては，年齢が若いほど治療効果があるという傾 向はみられなかった。

\section{3. 視力と届折度}

弱視眼屈折異常の種類は，遠視性屈折異常 66 例 (77\%), 近視性屈折異常18例 (21\%)であり, 遠視性の屈折異常の方がはるかに多かった（図 3 ). 乱視度については, 遠視性屈折異常の平均 乱視度 $0.99 \pm 1.25 \mathrm{D}$, 近視性 $3.61 \pm 1.76 \mathrm{D}$ と近 


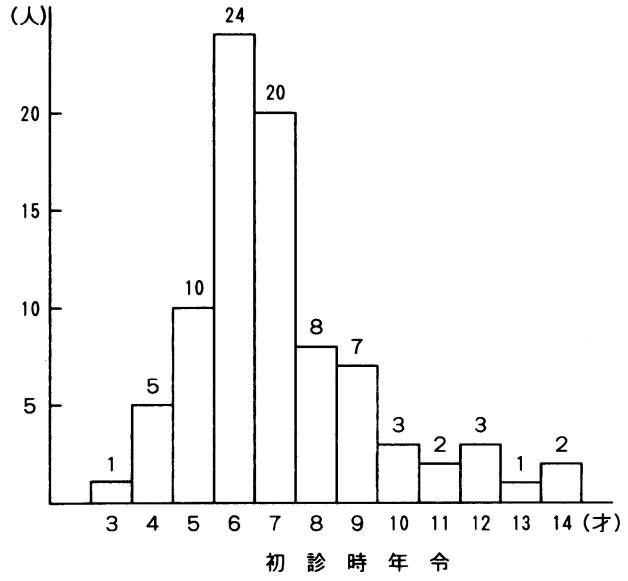

図 2. 初診時年齢の分布

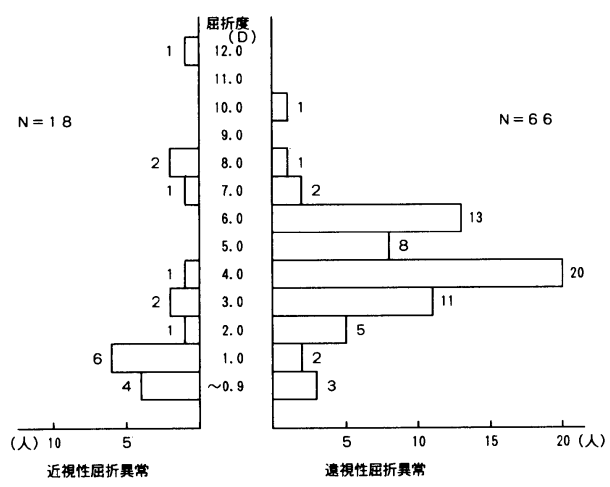

図 3. 弱視眼屈折異常の種類と程度

視性の屈折異常の方が乱視度が大きい傾向が見 られた。また弱視眼全体の $69 \%$ が乱視を有して いた。各群については $\mathrm{A}$ 群の平均乱視度1.89土

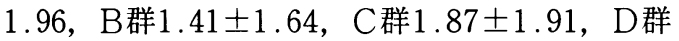
$1.49 \pm 1.74$ であり，どの群においても差はみら れなかった。

\section{4. 視力と不同視差}

不同視差は2.0D〜3.0Dが38例 (44\%) と 4 割 以上を占めていた (図 4 ). 弱視眼を遠視性のも のと近視性のものに分けて不同視差の比較を行 ったが，不同視差に有意な差はみられなかった。 A 群と B 群，またC群とD群について不同視差

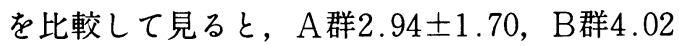
\pm 2.42 であり，有意な差は認められなかったが,

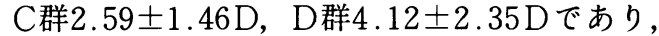
有意な差が見られ, 初診時視力の良好な $C$ 群の 方が不同視差が小さいということがわかった。 (図 5 )

\section{N. 考按}

不同視弱視の治療成績，予後に関しては従来 から数多くの研究報告がなされているが，必ず しも意見の一致は見られていない, 1,4,5),6). 不同 視弱視では屈折度および不同視差の程度の軽い ものの方が治療成績がよく，初診年齢は治療効 果にあまり関係しないとされているが5), 治療開 始時の視力は治療効果に関係するという報告?

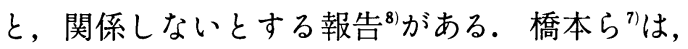

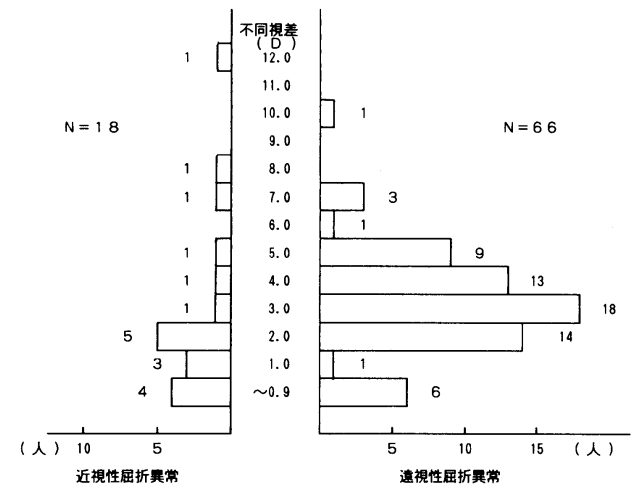

図 4. 弱視眼屈折異常の種類別不同視差

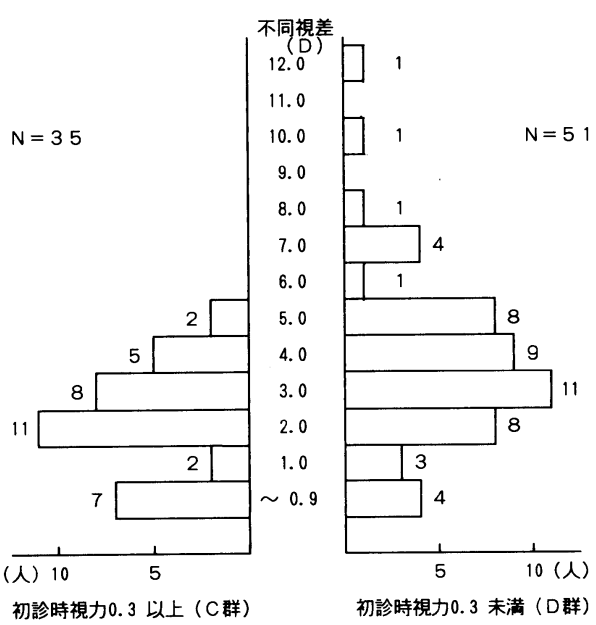

図 5.C群，D群における不同視差の分布 
最終視力が 0.8 以上に到達したものを健常化群, 0.8に達しなかったものを非健常化群として分類 し, 健常化群では22例中 15 例が 0.3 以上の初診時 視力を有していたが, 非健常化群では全例が 0.2 以下であったと報告している。私共も最終視力 を0.8以上 (A 群) と0.8末満 (B群) とに分類し検 討を試みたところ, 表 1 のように最終視力の悪 かったB群の方がわずかながら A 群に比べて初 診時視力の悪いものの占める割合が高かった。 そこで, 視力表にて初診時視力より何段階の視 力向上が見られたかを調べてみたが, 初診時視 力が 0.3 以上の症例も 0.3 未満の症例も大差はな く, 視力が向上する程度は初診時視力に関係が ないという結果となった. 臼井ら ${ }^{6}$ は, 不同視弱 視は治療前から中心固視で両眼視機能を有して いることから，その視力予後は概して良好と思 われがちであるが，実際には良好なものと不良 なものとがあり, 今迄の報告の多くは対象のお よそ半数が 0.8 未満にとどまっていると述べてい る. 今回，私共の取り扱った対象においても86 例中 44 例 $(51 \%)$ が最終視力 0.8 未満という結果 であり, 臼井らと同様不同視弱視の予後は良好 なものと不良なものがあると思われる。予後不 良の症例について考える時, 微小角斜視の存在 の有無が重要な問題であると思われるが, 今回 の症例ではその鑑別方法である $4 \Delta$ base out test $や$ after image transfer testが行われて いるものは少なく，これについて検討は加えな かった，最終視力が 0.8 以上となった 42 症例で は，全症例においてメガネあるいはコンタクト レンズの装用がきちんと行われていたが，最終 視力 0.8 未満であった 44 症例については，装用が ほとんどできていなかった症例が15例，治療途 中で数年間放置していた症例が 5 例含まれてお りより良い治療効果を得るためには患者およ びその家族の理解と協力も大切であると思われ た。

\section{V. 結 論}

不同視弱視患者86名について, 視力回復に関 与する因子について検討し, 以下の結果を得た. 1. 最終視力 0.8 以上と 0.8 未満の群とでは 0.8 未満の方が初診時視力の悪いものの占める割
合が高かった。

2. 初診時視力 0.3 以上と 0.3 未満の群とでは初 診時視力より何段階の視力向上が見られるか の程度に差は見られなかった。

3 . 初診時年齢, 弱視眼屈折度, 不同視差と視 力の間には関係は見られなかった。

4. 初診時視力 0.3 以上の群の方が 0.3 未満の群 に比べ不同視の程度が小さかった。

\section{参考文献}

1) 加藤和男 : 小児の屈折異常 弱視 不同視弱視 屈折性弱視 。 眼臨, $79: 521-528.1985$.

2 ) 井上浩彦: 不同視弱視, 屈折異常性弱視, 経線弱 視. 眼臨, $77: 1922-1931,1983$.

3）秋山明基, 長谷川正光：両眼弱視の治療について. 臨眼, $21: 245-255,1967$.

4 ）広石恂：不同視弱視. 眼紀，22:581，1971.

5 ）丸尾敏夫, 久保田伸枝: 屈折異常 弱視眼科, 19 : 1405-1410, 1977.

6 ） 白井千恵, 久保田伸枝: 不同視弱視. 眼科, 30 : 53-62, 1988.

7 ）橋本弘子, 平岩紀代美: 遠視性不同視弱視の治療 効果予測. Jpn. Orth. J. 11 : 126-129, 1983.

8) Scott, W. E. Stratton, V. B. and Fabre, J. : Full time occlusion therapy for amblyopia, Am. Orthopt. J., 30 : 125-130, 1980.

\section{告問}

（自治医大）山本裕子

多数のきれいな data を見せて頂きましてありがと うございました。

$1 つ た ゙ け ， 1 \mathrm{D}$ 未満の不同視の症例は，不同視以外 に，遠視度が強いとか，その他に何らかの異常があっ たものでしょうか.

\section{答弁}

対象を撰択する時に, 左右眼の屈折度数が $2 \mathrm{D}$ 以上 のものと乱視度が $1.5 \mathrm{D}$ 以上のものにとって, 最小錯乱 円として計算しるしたので不同視が1.0D未満となり ますと乱視が大きいとかの因子ができますので，その ようなデーターが出たものと思います。

\section{追加}

（岡山大）渡辺好政

臨床的に不同視を伴った弱視の中には，本来の不同 弱視のほか，はじめに斜視があって弱視となり，不同 視と弱視が残ったもの, 微小斜視弱視, その他のいろ いろな病態が含まれている可能性があります。また, 遠視系の不同視と近視系の不同視とでは弱視の発生に 異った要因が推定されます.

そこで，不同視弱視をとりあげられるときには，上 記の病態を念頭におかれまして, 症例の症歴, 経過な ぞを含めて, 症状をくわしく検索されることをおすす 
めします。

また，立体視につきましても，微小斜視では，TST は passしてTNOが十分に出ない症例もありますので, 立体視の検査法としては, TST+TNO としていただ ければ幸いです。
追加

（福島眼科医大）福島正大 不同視弱視で視力の向上が見られない場合, 不同視 の大きさ以外に微小角斜視や潜伏眼振, さらには遮閉 療法や眼鏡装用が充分できていないなど，もっと多く の因子を考える必要があると思います。 